\title{
Contamination of barberry with heavy metals in the vicinity of Qayen Cement Company, Khorasan, Iran, in 2014: A Case study
}

\author{
Rezaei MR, $\mathrm{PhD}^{1}$, Sayadi MH, $\mathrm{PhD}^{1 *}$, Khaksarnejad M, $\mathrm{MSc}^{2}$ \\ 1-Associate Prof., Dept. of Environmental Science, Faculty of Natural Resources and Environment, University of Birjand, \\ Birjand, Iran. 2- MSc Student, Dept. of Environmental Science, Faculty of Natural Resources and Environment, University of \\ Birjand, Birjand, Iran.
}

\begin{abstract}
Received: December 2015, Accepted: January 2016

Background: Soil pollution and accumulation of heavy metals in crops in industrial areas is one of the most important environmental issues threatening the life of plants, animals, and humans. The aim of this study was to determine the concentration of $\mathrm{Cr}$ and $\mathrm{Cd}$ in the soil and barberry plants in farms surrounding the Qayen Cement Company, South Khorasan Province, Iran.

Materials and Methods: In this study, 8 soil samples were collected from a depth of 0-30 cm and 30-60 $\mathrm{cm}$ and 4 samples of barberry plant containing fruits and leaves in summer 2014. The concentrations of $\mathrm{Cr}$ and $\mathrm{Cd}$ in the samples were determined using atomic absorption spectrometry.

Results: The maximum concentration of $\mathrm{Cr}$ and $\mathrm{Cd}$ was observed in the soil sample collected from a depth of $0-30 \mathrm{~cm}$ (95.10 and $1.32 \mathrm{mg} / \mathrm{kg}$ of soil, respectively). The concentration of $\mathrm{Cr}$ and $\mathrm{Cd}$ was higher in the fruits of barberry than the leaves; $18.58 \mathrm{mg} / \mathrm{kg}$ and $59.45 \mu \mathrm{g} / \mathrm{kg}$, respectively, which are higher than the standard values. Transfer factor was calculated as less than 1 for all stations.

Conclusions: According to obtained results, Qayen Cement Company has the greatest impact on plants in this region. The barberry fruit is the strategic product in Qayen; therefore, attention to and management of the impact of the cement factory on agricultural products is necessary.
\end{abstract}

Keywords: Heavy Metals, Transfer Factor, Cement, Barberry

\section{Introduction}

Contamination of the environment by heavy metals is a major concern because of their toxicity and threat to human life and the environment (1-4). Cement factories have been reported as a major source of heavy metals emission into the environment with several reports showing higher concentrations of heavy metals in the vicinity of cement factories (5-9).

Contamination of the environment with many pollutants is one of the most significant problems in this century. Some metals such as $\mathrm{Zn}, \mathrm{Ni}$, and $\mathrm{Fe}$ are essential for metabolism in trace amounts. However, other nonessentials, such as As and $\mathrm{Hg}$, have no biological role and are potentially toxic to living systems and they can be carried through soil-plant-animalhuman cycles (10-12).

Generally, if the concentration of heavy metals in the soil increases, the amount available for the plants also increases (13). Some factors of importance in the determination of the amount of heavy metals uptake by plants include the chemical form of the element, heavy metal concentration, soil $\mathrm{pH}$, and plant species (14). The maximum amount of heavy metals are released into the soil via the use of sewage sludge in agricultural soils and human industrial

\footnotetext{
Corresponding author: Mohmmad Hossein Sayadi, Dept. of Environmental Science, Faculty of Natural Resources and Environment, University of Birjand, Birjand, Iran. Email: mh_sayadi@yahoo.com
} 
activities such as paint, cement, rubber, soil phosphate fertilizer, fuel, and metal smelting industries (15).

Kabata and Pendias believe that a very small amount of heavy metals are absorbed from the soil by most crops (16). The uptake of heavy metals from polluted lands by plants, and especially agricultural products, is the most important issues in the food chain $(16,17)$.

A study conducted in Turkey showed that the concentration of $\mathrm{Cr}$ was higher in plants, soil, and blood of humans in areas surrounding the cement plant than others, showing the toxic effects of $\mathrm{Cr}$ (18).

Thus, the aim of this study was to determine the concentrations of toxic metals of $\mathrm{Cr}$ and $\mathrm{Cd}$ in the soil and the barberry plant farms around Qayen Cement Company, South Khorasan Province, Iran.

\section{Material and Methods}

Study area: Qayen city is located in the north of South Khorasan Province, with an area of $17,722 \mathrm{Km}^{2}$. Qayen is located within latitude of $33^{\circ} .43^{\prime \prime}$ and longitude of $59^{\circ} .11^{\prime \prime}$ and it is 1440 meters above sea level. The weather is strongly affected by mountains which surround this city. This area is a cold region in the Köppen climate classification and its dominant winds blow from the eastern region. The Qayen Cement Company is located $10 \mathrm{~km}$ from Qayen, on the road from Qayen to Birjand. The operation of the Qayen Cement Company began in January 1995. The products of this company include Portland cement type 1-325, type 1-425, type 2, type 5, and Pozzolanic Portland cement. Figure 1 shows the study area and the location of sampling stations.
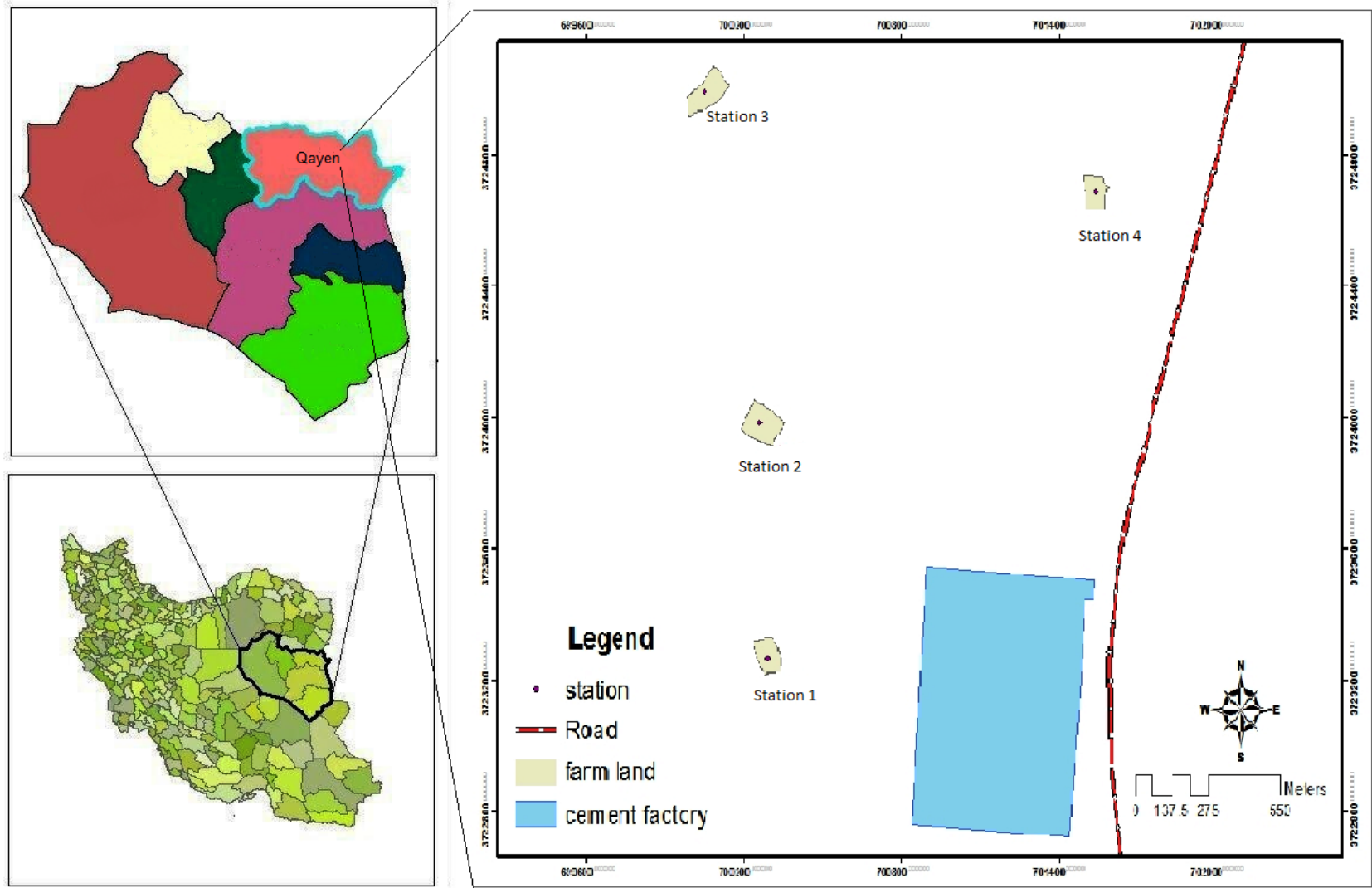

Figure 1: Map of the study area and sampling stations

Sampling: To check the status of heavy metals in 12 samples, a distance range of 500-800 meters around a cement plant was monitored in 2014. Thus, 8 soil samples were collected from around the Qayen Cement Company at two depths of $0-30 \mathrm{~cm}$ and $30-60 \mathrm{~cm}$ and 4 plant samples containing barberry fruits and leaves. Then, the samples were transported to the 
laboratory for further analysis. Containers and sampling equipment, sampling techniques, and maintenance, consolidation, and transmission of samples to laboratories were based on standard methods. The concentrations of heavy metals of $\mathrm{Cr}$ and $\mathrm{Cd}$ through chemical digestion were measured using atomic absorption spectrometry.

Plant analysis: Plant samples were washed thoroughly with deionized water to remove surface dust and soil, and further separated into roots, shoots, and leaves. The samples were then air-dried, chopped, and further dried for 24 hours in an oven at $70{ }^{\circ} \mathrm{C}$, and weighed using a balance with an accuracy of up to $0.001 \mathrm{~g}$. The dried plant samples were finely ground, mixed thoroughly, and $1 \mathrm{~g}$ of the samples was digested in a borosilicate conical glass flask with 5:1 mixture of $\mathrm{HNO}_{3}$ and $\mathrm{HClO}_{4}(20)$ at $70-80{ }^{\circ} \mathrm{C}$ on a hot plate. After digestion, the samples were placed in ambient air to cool. The samples were filtered using Whatman filter paper $0.45 \mu \mathrm{m}$ and placed inside the box (19).

Soil analysis: Soil samples were prepared by air-drying, and then, passing samples through a $63 \mu \mathrm{m}$ mesh (equivalent to a No. 230 sieve, ASTM E-11). About $0.5 \mathrm{~g}$ of the sample was placed in a beaker containing $5 \mathrm{ml}$ of 3:1 $\mathrm{HNO} 3$ to $\mathrm{HCl}$ and covered with a watch glass. Subsequently, samples were heated until most of the liquid had evaporated, and allowed to cool before $3 \mathrm{ml}$ of $\mathrm{HClO}_{4}$ was added. The covers were replaced and the samples heated again until evaporation of most of the liquid. Finally, samples were cooled to room temperature before being filtered (20).

Transfer factor: The transfer factor (TF) is the motion of a heavy metal from the leaves to the fruit, which was assessed using the subsequent formula (21):

$\mathrm{TF}=[$ Element of fruit $(\mathrm{mg} / \mathrm{kg}) /$ Element of leaves

$$
(\mathrm{mg} / \mathrm{kg})] \times 100
$$

A TF of less than 1 indicates that the metals are stored in the roots of the plant, and TF of higher than 1 shows translocation of metals to the shoots of the plant.

Statistical analysis: All the data were statistically analyzed using Excel and SPSS software (version 16, SPSS Inc., Chicago, IL, USA). Results were analyzed using descriptive and analytical statistics by box plot, and the Pearson coefficient was used to determine correlations between data.

\section{Results}

Descriptive statistics of total metal contents of the soil and plant samples are presented in tables 1 and 2. The presented results show that the highest mean concentration of $\mathrm{Cr}$ and also the maximum amount of $\mathrm{Cr}(95.10 \mathrm{mg} / \mathrm{kg})$ was in the depth of 0-30 cm. In addition, the highest mean concentration of $\mathrm{Cd}$ and maximum amount of this metal $(1.32 \mathrm{mg} / \mathrm{kg})$ was at the depth of 0-30.

Table 1: Descriptive statistics of total metal contents of the soil of the study area

\begin{tabular}{ccccccc}
\hline \multirow{2}{*}{ Depth (cm) } & \multicolumn{3}{c}{ Cr $(\mathbf{m g} / \mathbf{k g})$} & \multicolumn{3}{c}{ Cd (mg/kg) } \\
\cline { 2 - 7 } & Maximum & Minimum & Mean \pm SD & Maximum & Minimum & Mean \pm SD \\
\hline $0-30$ & 95.10 & 52.10 & $72.48 \pm 17.94$ & 1.32 & 1.16 & $1.21 \pm 0.07$ \\
\hline $30-60$ & 68.75 & 22.29 & $35.56 \pm 22.18$ & 1.27 & 0.03 & $0.65 \pm 0.58$ \\
\hline
\end{tabular}

Typically, the concentration range of $\mathrm{Cd}$ is 7$0.01 \mathrm{mg} / \mathrm{kg}$ and its limit of toxicity in the soil has been reported as $3 \mathrm{mg} / \mathrm{kg}(22)$. The results showed that with increasing of depth of soil, the concentration of $\mathrm{Cd}$ decreased, indicating nonleaching of $\mathrm{Cd}$ in the soil layer. The leaching of heavy metals was not possible in sub-soil layers due to presence of more than $40 \%$ limestone $\left(\mathrm{CaCO}_{3}\right)$ and alkalinity of soil. The maximum concentration of $\mathrm{Cd}$ in the depth of $30-60 \mathrm{~cm}$ was 1.27 that is less than the surface layer of the soil. 
Table 2: Descriptive statistics of total metal contents of the plants of the study area

\begin{tabular}{ccccccc}
\hline \multirow{2}{*}{ Plant } & \multicolumn{3}{c}{ Cr $(\mathbf{m g} / \mathbf{k g})$} & \multicolumn{3}{c}{ Cd $(\boldsymbol{\mu g} / \mathbf{k g})$} \\
\cline { 2 - 7 } & Maximum & Minimum & Mean \pm SD & Maximum & Minimum & Mean \pm SD \\
\hline Barberry fruit & 18.58 & 15.53 & $17.38 \pm 1.31$ & 59.45 & 30.44 & $41.87 \pm 14.00$ \\
\hline Barberry leaf & 15.35 & 11.04 & $13.15 \pm 2.13$ & 30.49 & 21.46 & $26.29 \pm 3.77$ \\
\hline
\end{tabular}

In the presented study, the transfer factor of $\mathrm{Cr}$ and $\mathrm{Cd}$ was measured at 4 stations. The results showed that the metals are stored in the fruit of

Table 3: Transfer factor values for the measured heavy metals in plants in the study area

\begin{tabular}{ccc}
\hline \multirow{2}{*}{ Station } & \multicolumn{2}{c}{ Transfer factor (TF) } \\
\cline { 2 - 3 } & \multicolumn{2}{c}{ Barberry leaf to fruit } \\
\cline { 2 - 3 } & $\mathbf{C r}$ & $\mathbf{C d}$ \\
\hline 1 & 0.87 & 0.84 \\
\hline 2 & 0.61 & 0.51 \\
\hline 3 & 0.74 & 0.69 \\
\hline 4 & 0.78 & 0.58 \\
\hline
\end{tabular}

The Pearson correlation coefficient can be used to measure the degree of correlation between the logarithms of the data on heavy metals (26). The correlation coefficient is presented in table 4 . The results show a significant positive correlation between $\mathrm{Cr}$ and $\mathrm{Cd}$ in the fruit $(\mathrm{P}=$ 0.05) ( $\mathrm{r}=0.627)$. Furthermore, a significant negative correlation was observed between $\mathrm{Cr}$ barberry and the highest transfer factor was observed at the first station (Table 3 ).

Table 4: Pearson correlation coefficients of parameters under study

\begin{tabular}{|c|c|c|c|c|c|c|c|c|}
\hline Metal & $\mathrm{Cr}$ in the fruit & $\begin{array}{l}\text { Cr in the } \\
\text { leaf }\end{array}$ & $\begin{array}{l}\text { Cd in the } \\
\text { fruit }\end{array}$ & $\begin{array}{c}\text { Cd in the } \\
\text { leaf }\end{array}$ & $\begin{array}{c}\mathrm{Cr} \text { in the soil } \\
\text { at depth of } 0 \text { - } \\
30 \mathrm{~cm}\end{array}$ & $\begin{array}{c}\text { Cr in the soil at } \\
\text { depth of } 30-60 \\
\mathrm{~cm}\end{array}$ & $\begin{array}{c}\text { Cd in the } \\
\text { soil at depth } \\
\text { of } 0-30 \mathrm{~cm}\end{array}$ & $\begin{array}{c}\text { Cd in the } \\
\text { soil at depth } \\
\text { of } 30-60 \mathrm{~cm}\end{array}$ \\
\hline $\mathrm{Cr}$ in the fruit & 1 & & & & & & & \\
\hline $\mathrm{Cr}$ in the leaf & 0.129 & 1 & & & & & & \\
\hline Cd in the fruit & $0.627^{*}$ & 0.473 & 1 & & & & & \\
\hline Cd in the leaf & 0.456 & $-0.699^{* *}$ & -0.186 & 1 & & & & \\
\hline $\begin{array}{l}\text { Cr in the soil at } \\
\text { depth of } 0-30 \mathrm{~cm}\end{array}$ & 0.489 & 0.575 & -0.004 & 0.459 & 1 & & & \\
\hline $\begin{array}{c}\text { Cr in the soil at } \\
\text { depth of } 30-60 \mathrm{~cm}\end{array}$ & 0.108 & 0.716 & -0.498 & -0.037 & 0.869 & 1 & & \\
\hline $\begin{array}{l}\text { Cd in the soil at } \\
\text { depth of } 0-30 \mathrm{~cm}\end{array}$ & 0.227 & 0.598 & -0.284 & 0.181 & $0.955^{*}$ & $0.967^{*}$ & 1 & \\
\hline $\begin{array}{l}\text { Cd in the soil at } \\
\text { depth of } 30-60 \mathrm{~cm}\end{array}$ & -0.619 & 0.420 & $-0.968^{*}$ & -0.775 & 0.204 & 0.654 & 0.481 & 1 \\
\hline
\end{tabular}

* Correlation is significant at $\mathrm{P}=0.05$ (2-tail)

** Correlation is significant at $\mathrm{P}=0.01$ (2-tail)

and $\mathrm{Cd}$ in leaves $(\mathrm{P}=0.01)(\mathrm{r}=-0.699) . \mathrm{Cd}$ in the soil at depth of $0-30 \mathrm{~cm}$ had a significant positive correlation with $\mathrm{Cr}$ in the soil at depth of $0-30 \mathrm{~cm}$ and $\mathrm{Cr}$ in the soil at depth $30-60 \mathrm{~cm}$ $(\mathrm{P}=0.05)(\mathrm{r}=0.955, \mathrm{r}=0.967)$. A significant negative correlation was observed between $\mathrm{Cd}$ in the soil (depth of 30-60 cm) and $\mathrm{Cd}$ in the fruit $(P=0.05)(r=-0.968)$. 


\section{Discussion}

$\mathrm{Cd}$ has been reported to be released into the environment a result of raw material used in cement production (23), but generally at low concentrations (6).

In a previous study, the emission of heavy metals into the soil samples from the area surrounding the cement plant in the South of Jordan was demonstrated. The results showed that the mean concentration of $\mathrm{Cr}$ and $\mathrm{Cd}$ in 0 $10 \mathrm{~cm}$ was 22.18 and $5 \mathrm{mg} / \mathrm{kg}$, and at a depth of $10-20 \mathrm{~cm}$ was 6 and $2.18 \mathrm{mg} / \mathrm{kg}$, respectively (24). Moreover, a research surveyed the pollution of soils by heavy metals in the area surrounding a cement plant and showed that the mean concentration of $\mathrm{Cr}$ and $\mathrm{Cd}$ was 83.2 and $0.9 \mathrm{mg} / \mathrm{kg}$, respectively (24).

The amount of $\mathrm{Cd}$ in barberry fruit and leaf was higher than $\mathrm{Cr}$. In addition, the accumulation of $\mathrm{Cr}$ and $\mathrm{Cd}$ was greater in barberry fruit than its leaves. The maximum concentration of $\mathrm{Cd}$ in the fruit of barberry was $59.45 \mu \mathrm{g} / \mathrm{kg}$ and the leaf of barberry was $30.49 \mu \mathrm{g} / \mathrm{kg}$. The maximum concentration of $\mathrm{Cr}$ in the fruit of barberry was $18.58 \mathrm{mg} / \mathrm{kg}$ and its concentration in the leaves was $15.35 \mathrm{mg} / \mathrm{kg}$. An investigation of the concentration of $\mathrm{Cr}$ in the soil and plants surrounding cement factories in Ardebil demonstrated that $\mathrm{Cr}$ concentration in grasses and shrubs was 7.21 and $12.08 \mathrm{mg} / \mathrm{kg}$, respectively (25). As tables 1 and 2 show, the highest concentration of $\mathrm{Cd}$ was observed in the barberry fruit.The concentration of $\mathrm{Cd}$ was greater in the depth of 0-30 cm than the depth of $30-60 \mathrm{~cm}$. The concentration of $\mathrm{Cr}$ was higher in the barberry fruit than barberry leaves and showed less changes compared to the amount of $\mathrm{Cr}$ in the soil. $\mathrm{Cr}$ changes range was uniform in the depth of $0-30 \mathrm{~cm}$, but there was a greater range of change at the depth of $30-60 \mathrm{~cm}$. Figure 2 shows more changes in $\mathrm{Cd}$ concentration in the fruit and leaves of barberry and soil at depth of 30-60 cm. Nevertheless, drastic changes were not observed in the soil at the depth of $0-30 \mathrm{~cm}$ in the stations. In the second station, the maximum concentration of $\mathrm{Cd}$ in barberry fruit and leaf was 59.45 and $30.49 \mu \mathrm{g} / \mathrm{kg}$, respectively. In the first station, the concentration of $\mathrm{Cd}$ was lower in the soil; the maximum concentration of $\mathrm{Cd}$ in the depths of $0-30$ and $30-60 \mathrm{~cm}$ was 1.32 and $1.27 \mathrm{mg} / \mathrm{kg}$, respectively.

The maximum concentration of $\mathrm{Cr}$ in the barberry fruit was $17.97 \mathrm{mg} / \mathrm{kg}$ in the second station and in the barberry leaf was $15.35 \mathrm{mg} / \mathrm{kg}$ in the first station. In the first station, the maximum concentration of $\mathrm{Cr}$ was 95.10 and $68.75 \mathrm{mg} / \mathrm{kg}$ in the soil samples from a depth of 0-30 and 30-60 cm, respectively. In the third station, the minimum concentration of $\mathrm{Cr}$ was 52.10 and $22.29 \mathrm{mg} / \mathrm{kg}$ in soil samples from depths of $0-30$ and $30-60 \mathrm{~cm}$, respectively (Figure 3).

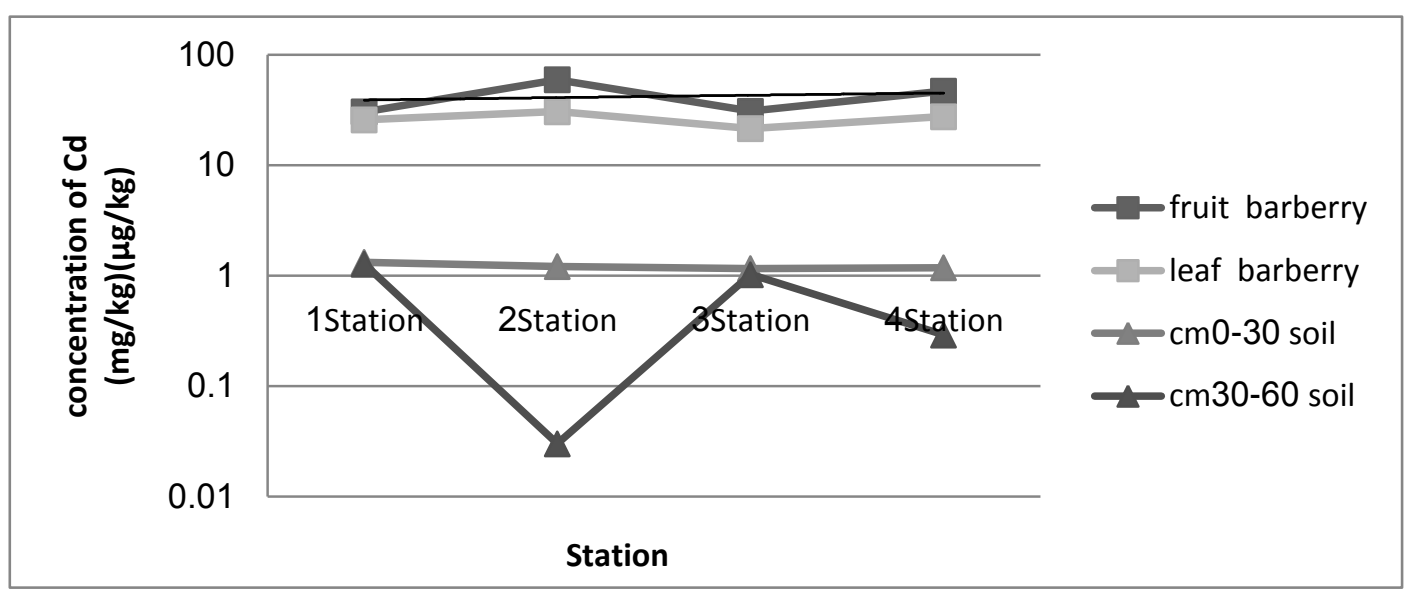

Figure 2: Comparison of $\mathrm{Cd}$ concentrations in plants and soil at different stations 


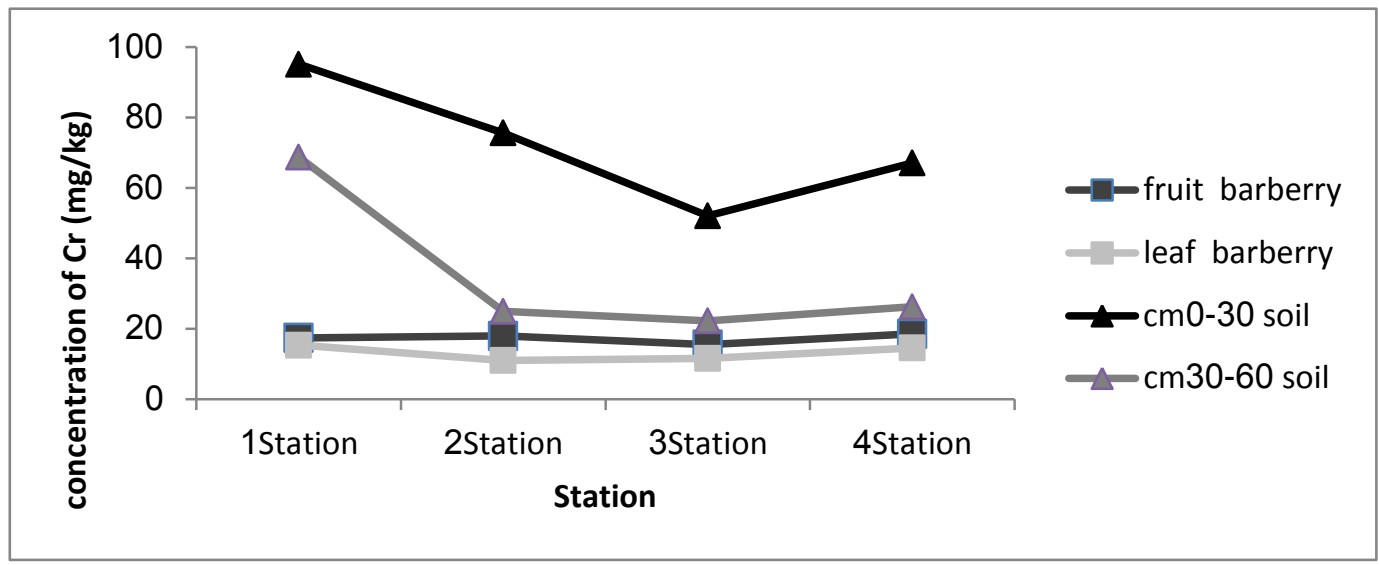

Figure 3: Comparison of $\mathrm{Cr}$ concentrations in plants and soil at different stations

In the present study, the lowest rate of absorption and accumulation of heavy metals belonged to $\mathrm{Cd}$ and the highest to $\mathrm{Cr}$. Thus, the trend of the concentration change was relatively normal and predictable. The concentration of unhealthy elements such as $\mathrm{Cd}$ is generally lower in the environment, while the concentration of $\mathrm{Cr}$ is pronounced in the Earth's crust and it enters the environment and its concentration is increased through mining and cement production at different levels. The average concentrations of $\mathrm{Cr}$ and $\mathrm{Cd}$ were higher in the depths of $0-10 \mathrm{~cm}$ than $10-20 \mathrm{~cm}$ (26). The concentrations of $\mathrm{Zn}, \mathrm{Cr}$, and $\mathrm{Pb}$ were 132,57 , and $32 \mathrm{mg} / \mathrm{kg}$, respectively, in soil samples collected from the area surrounding a cement plant (9). The reported concentrations are relatively high (9).

Mosavi at al., by calculating the correlation coefficient, showed that a significant correlation exists between heavy metals in all the sampling points, such as the $\mathrm{Cr}-\mathrm{Ni}, \mathrm{Cu}-\mathrm{Ni}, \mathrm{Zn}-\mathrm{Co}, \mathrm{Cd}-\mathrm{Cu}$, and Ni-Co correlations (27).

In the present study, a significant negative correlation $(\mathrm{P}=0.05) \quad(\mathrm{r}=0.383)$ was found between $\mathrm{Cr}$ and $\mathrm{Cd}$ in the soil samples from the area surrounding the mega cement plant by studying the correlation between different metals. Furthermore, the presence of $\mathrm{Cd}$ in the soil to some extent can the emissions from cement production and a significant correlation with $\mathrm{Pb}$ and $\mathrm{Cu}$ (28). The results of a study on heavy metal pollution in soil and plants in the vicinity of the cement plant in Volta Region, Ghana, showed a positive correlation between soil and plant samples (excluding $\mathrm{Zn}$ and $\mathrm{Ni}$ ) through analysis of heavy metals in soil and plants. However, in the present study, a negative correlation was observed between the soil and plant samples (29).

\section{Conclusion}

The results obtained in this study illustrate that the concentration of $\mathrm{Cd}$ and $\mathrm{Cr}$ in barberry fruit of was higher than barberry leaves and their concentration was higher in 0-30 cm. Transfer factor for all stations was less than one. The concentration of $\mathrm{Cd}$ and $\mathrm{Cr}$ in the barberry plant was higher than standard levels, but their concentration in the soil was in the standard range. Thus, heavy metal pollution caused by Qayen Cement Company has the greatest impact on plants of the region, and since the barberry plant is a strategic product, necessary measures should be taken to reduce this pollution.

\section{Acknowledgments}

This study was funded by the Research Council of University of Birjand which as a Research Project was conducted in 2015. Authors are appreciated the authorities of Research Council and Faculty of Natural Resources and Environment, University of Birjand, due to their sincere cooperation. 
Conflict of interest: None declared

\section{References}

1. Sakai T, Morita Y, Araki T, Kano M, Yoshida T. Relationship between delta-aminolevulinic acid dehydratase genotypes and heme precursors in lead workers. Am J Ind Med 2000; 38(3):35560.

2. Sayadi MH, Sayyed MRG, Shabani N. Quantification of heavy metal pollutants in the surface soils of chitgar industrial area (Tehran, Iran) with spatial references to their spatial pattern. Pollution Research 2009; 28(3):1-8.

3. Sayadi MH, Torabi S. Geochemistry of soil and human health: A review. Pollution Research 2009; 28(2):257-62.

4. Ceccatelli S, Dare S, Moors M. Methylmercuryinduced neurotoxicity and apoptosis. Chem Biol Interact 2010; 188(2):301-8.

5. Isikli B, Demir TA, Ürer SM, Berber A, Akar T, Kalyoncu C. Effects of chromium exposure from a cement factory. Environ Res 2003; 91(2):113-8.

6. Al-Khashman OA, Shawabkeh RA. Metals distribution in soils around the cement factory in southern Jordan. Environ Pollut 2006; 140(3):387-94.

7. Abimbola AF, Kehinde-Phillips OO, Olatunji AS. The Sagamu cement factory, SW Nigeria: is the dust generated a potential health hazard? Environ Geochem Health 2007; 29(2):163-7.

8. Gbadebo AM, Bankole OD. Analysis of potentially toxic metals in airborne cement dust around Sagamu, southwestern Nigeria. J Appl Sci 2007; 7:35-40.

9. Mandal A, Voutchkov M. Heavy metal in soils around the cement factory in Rockfort, Kingston, Jamaica. International Journal of Geosciences 2011; 2:48-54.

10. Akar T, Akar ST. Biosorption performance of botrytis cinerea fungal by-products for removal of $\mathrm{Cd}(\mathrm{II})$ and $\mathrm{Cu}$ (II) ions from aqueous solutions. Miner Eng 2005; 18(11):1099-109.

11. Rashki Ghaleno O, Sayadi MH, Rezaei MR. Potential ecological risk assessment of heavy metals in sediments of water reservoir case study: Chah Nimeh of Sistan. Proceedings of the International Academy of Ecology and Environmental Sciences 2015; 5(4):89-96.

12. Hosseini-Alhashemi A, Karbassi AR, Hassanzadeh-Kiabi B, Monavari SM, Nabavi MB. Accumulation and bioaccessibility of trace elements in wetland sediments. Afr J Biotechnol 2011; 10(9):1625-36.
13. Zojaji F, Hassani AH, Sayadi MH, Bioaccumulation of chromium by Zea mays in wastewater-irrigated soil: An experimental study. Proceedings of the International Academy of Ecology and Environmental Sciences 2014; 4(2):62-7.

14. Zojaji F, Hassani A H, Sayadi MH. A comparative study on heavy metal content of plants irrigated with tap and wastewater. Int $\mathbf{J}$ Environ Sci Technol 2015; 12:865-70. DOI 10.1007/s13762-014-0698-5

15. Pal M, Horvath E, Janda T, Paldi E, Szalai G. Physiological changes and defense mechanisms induced by cadmium stress in maize. J Plant Nutr Soil Sci 2006; 169(2):239-46.

16. Kabata-Pendias A, Pendias H. Trace Elements in Soils and Plants. $2^{\text {nd }}$ ed. Florida: CRC Press, Boca Raton; 1991.

17. Sayadi MH, Kargar R, Doosti MR, Salehi H. Hybrid constructed wetlands for wastewater treatment: a worldwide review. Proceedings of the International Academy of Ecology and Environmental Sciences 2012; 2(4):204-22.

18. Shanker AK, Cervantes C, Loza-Tavera H, Avudainayagam S. Chromium toxicity in plants. Environ Int 2005; 31(5):739-53.

19. Allen SE. Chemical analysis of ecological materials. $2^{\text {nd }}$ ed. Britain: Blackwell Science Inc; 1990.

20. Page AL, Miller RH, Keene ${ }^{y}$ DR. 1982. Methods of Soil Analysis. Madison, Wisconsin, USA

21. Kim IS, Kang KH, Johnson-Green P, Lee EJ. Investigation of heavy metal accumulation in Polygonum thunbergii for phytoextraction. Environ Pollut 2003; 126(2):235-43.

22. Istvan Pais J, Benton Jones Jr. The handbook of trace elements. Florida: CRC Press, Taylor \& Francis Group; 1997.

23. Scoullos MJ, Vonkeman GH, Thornton I, Makuch Z. Mercury - Cadmium - Lead: Handbook for sustainable heavy metals policy and regulation. 1st ed. Scoullos MJ, ed. United States of America: Springer, Environment \& Policy; 2001. P.71-2.

24. Al-Khashman OA. Determination of metal accumulation in deposited street dusts in Amman, Jordan. Environ Geochem Health 2007; 29(1):1-10.

25. Tavankar F, Shafaghat A. survey the concentration of chromium in soil and surrounding plants Cement Factory of Ardebil. Paper presented at: The second regional conference on natural resources and the environment; 2008; Arsanjan, Iran.

26. Garcia R, Millan E. Assessment of $\mathrm{Cd}, \mathrm{Pb}$ and $\mathrm{Zn}$ contamination in roadside soils and grasses from Gipuzkoa (Spain). Chemosphere 1998; 37(8):1615-25. 
27. Moosavi MH, Pournia M, Amiri F. Metals distribution in agricultural soils around the karoon cement factory, SE of Masjed Soleiman. Geochemistry 2013; 1(3):215-26.

28. Ogunkunle CO, Fatoba PO, Contamination and spatial distribution of heavy metals in topsoil surrounding a mega cement factory. Atmo Pollut
Res 2014; 5(2):270-82.

29. Addo MA, Darko EO, Gordon C, Nyarko BJB, Gbadago LJK, Nyarko E, et al. Evaluation of heavy metals contamination of soil and vegetation in the vicinity of a cement factory in the volta region, Ghana. Int $\mathrm{J}$ Environ Sci Technol 2012; 2(1):40-50. 